\title{
Migracijska i etnička obilježja stanovništva kao čimbenici promjene kulturnoga pejzaža zagrebačke Dubrave
}

\begin{abstract}
SAŽETAK
Migracijska i etnička obilježja stanovništva, uz opće kretanje, naseljenost, dobnu, socioekonomsku, rasnu, pa čak i spolnu strukturu stanovništva, utječu na promjenu kulturnoga pejzaža nekoga područja. Pokazuje se to na primjeru zagrebačke Dubrave analizom osnovnih demografskih pokazatelja i njihovih odraza u vidljivome prostoru. Studijom slučaja istražen je utjecaj Janjevaca na dio pejzaža Dubrave, preciznije na trgovačku Konjščinsku ulicu. Istraživanje je pokazalo da se »uži« dio Dubrave u najvećoj mjeri naseljavao od 1950. do 1970. te da je na porast broja stanovnika najviše utjecalo doseljavanje iz drugih dijelova Hrvatske i iz BiH. Premda su prvi doseljenici ostavljali svoj trag u pejzažu koji su naseljavali, pa se prije u dijelovima s individualnom gradnjom moglo prepoznati u kojem području žive koji doseljenici, danas je to gotovo ili čak potpuno neprimjetno. Dugogodišnji suživot i noviji trendovi kopiranja u građevinarstvu i uređenju okućnica umanjili su ili izbrisali razlike u kulturnom pejzažu. Jedino se još u golemim, estetski, funkcionalno i fizionomski bitno različitim kućama u Konjščinskoj ulici, mogu uočiti utjecaji koje neka etnička grupa može imati na neposredni, vidljivi kulturni pejzaž.
\end{abstract}

KLJUČNE RIJEČI: kulturni pejzaž, stanovništvo, doseljavanje, etnička struktura, Janjevci, Konjščinska ulica, Dubrava

\section{UVOD}

Promatranjem uzročno-posljedičnih veza stanovništva i vidljivih odraza koje ono ostavlja u području koje naseljava, čime ga stalno mijenja, može se ustvrditi da su promjene kulturnih pejzaža u velikoj mjeri povezane s općim kretanjem stanovništva, gustoćom naseljenosti, migracijskim obilježjima, dobnom, socioekonomskom, narodnosnom, rasnom i u manjoj mjeri spolnom strukturom stanovništva. Primjerice valja očekivati da gušće naseljeni urbani pejzaži imaju neke specifičnosti u odnosu na slabije naseljene (primjerice veći udio izgrađenih površina, više javnih objekata, bolju infrastrukturnu mrežu i sl.). Isto tako, područja u kojima živi mlado stanovništvo imaju veći potencijal da se brže mijenjaju te se u njima nalaze 
sadržaji koji će pratiti pozitivno prirodno kretanje stanovništva (npr. više dječjih igrališta). U područjima s povoljnijom obrazovnom strukturom stanovništva može se očekivati veći broj obrazovnih i kulturnih institucija, područja s većim udjelom doseljenika znatno se mijenjaju jer doseljenici u njih prenose svoje običaje iz područja iseljavanja, dok će se u područjima s povoljnijom ekonomskom strukturom stanovništva u pejzažima primijetiti kvalitetnije i estetski dojmljivije izgrađene kuće i bolja uređenost okoliša nego u onima s nepovoljnijom ekonomskom strukturom, gdje se može očekivati nekvalitetna, stihijska gradnja te iznimno onečišćen okoliš (npr. u slamovima) (Crljenko, 2012a).

Mnogi primjeri u literaturi idu u prilog tim pretpostavkama, a ovdje će se izdvojiti tri. P. E. Lewis (1979) uputio je na primjeru SAD-a na razlike u kulturnim pejzažima koje su posljedica različite rasne strukture stanovništva. Primijetio je da ako dio države (ili čak dio grada) izgleda znatno drukčije od ostatka države (grada), postoji velika vjerojatnost da su i kulturne prakse stanovništva u tima dvama područjima bitno različite. Tako je, prema njemu, »južnjački« izgled američkih gradova na jugu SAD-a posljedica ne samo drukčije klime i vegetacije nego i različitih kulturnih tradicija stanovništva u odnosu na ostatak SAD-a (Crljenko, 2012a prema Lewis, 1979). Drugi primjer upućuje na to kako se jezična struktura stanovništva očituje u kulturnim pejzažima. Skladan suživot u višejezičnome društvu može se iščitati iz činjenice da u nekim istarskim gradovima postoje dvojezični natpisi imena ulica i trgova (Crljenko, 2008). Winchester, Kong i Dunn (2003: 86) iznose primjer stambene izgradnje Aboridžina u Australiji i odnosa vlasti prema njima, što jasno pokazuje moć koju vlast očituje u pejzažu. Prvotna segregacija Aboridžina u pejzažu jasno se vidi u osnivanju rezervatâ.

Da bismo ostvarili svrhu ovoga rada, a to je otkrivanje odnosâ kulturnih pejzaža i demografskih karakteristika stanovništva zagrebačke Dubrave, poglavito njegovih migracijskih i etničkih obilježja, krenuli smo od ostvarivanja njegova cilja, a to je analiza osnovnih demografskih obilježja - općega kretanja i distribucije stanovništva Dubrave, migracijskih obilježja te narodnosne strukture stanovnika Dubrave - te analiza odraza tih obilježja u vidljivome pejzažu. Budući da Dubravu u radu ponajprije promatramo s njezina kulturnogeografskoga, a ne demogeografskoga aspekta, u njemu smo istražili samo one demografske pokazatelje koji se smatraju relevantnima za ostvarivanje cilja. Radi upućivanja na promjene pejzaža nastale pod izravnim utjecajem jedne etničke grupe, ${ }^{1}$ u radu se primjenom studije slučaja

1 Prema Leksikonu migracijskog i etničkog nazivlja (1998: 54), etnička skupina označava »...jednu ili više skupina ljudi, odnosno zajednicu, čiji pripadnici dijele zajednički identitet na temelju iste kulture, religije, jezika, običaja i drugih čimbenika...« (1998: 54), dok se pojam etničke grupe ne definira, već se upućuje na etničku skupinu, iz čega se može zaključiti da je posrijedi sinonim. Prema sociolozima, Janjevce možemo smatrati etničkom skupinom. Tako kad nabrajaju različite etničke 
analizira utjecaj Janjevaca na krajnji zapadni dio Dubrave.

U radu upotrebljavamo statističku metodu, utemeljenu na podacima službene popisne statistike, kartografsku metodu, za prikazivanje pojedinih pojava i procesa, deskriptivnu metodu, za kulturnogeografsko opisivanje najistaknutijih elemenata kulturnog pejzaža (kuća, okućnica, ograda, ulice) u Konjščinskoj ulici, te analizu sekundarnih izvora, poput novinskih članaka, za kontekstualiziranje problematike doseljavanja prvih Janjevaca u Dubravu i njihova okupljanja oko jedne ulice. Prilikom terenskog istraživanja, provedenoga u ožujku 2010., upotrijebljena je i metoda neposrednoga promatranja kulturnoga pejzaža, radi prikupljanja vizualnih informacija iz neposredne stvarnosti, odnosno da bi se detektiralo i fotografski dokumentiralo trenutačno stanje pejzaža Dubrave, osobito Konjščinske ulice. Taj je fotografski materijal, uz novinske tekstove, upotrijebljen za opis različitih elemenata pejzaža (ponajviše za kuće i trgovine u Konjščinskoj ulici) te njezina uopćenog izgleda. Osim toga upotrijebljena je i metoda nestrukturiranog intervjua, odnosno neformalnog razgovora s Pavlom Palićem, predsjednikom Hrvatskoga društva »Janjevo« i aktivnim sudionikom kulturnih događanja vezanih uza zagrebačke Janjevce na temu Dubrave i Janjevaca. Razgovor je vođen 3. srpnja 2010. s ciljem da se saznaju činjenice, ali i osobna priča jednoga dubravačkog Janjevca, odnosno da se očima Janjevaca rasvijetli kontekst razvoja, širenja i promjene Dubrave.

\section{DOSADAŠNJA ISTRAŽIVANJA I IZVORI}

O Dubravi općenito, poglavito o njezinu stanovništvu, pejzažu i promjenama u suvremeno doba, malo je objavljenih istraživanja. Ipak valja izdvojiti radove sociologâ iz Instituta za migracije i narodnosti i Odsjeka za sociologiju Filozofskog fakulteta, koji su proveli opsežno istraživanje o demografskim obilježjima, sociokulturnim obrascima te socijalnoj integraciji i dezintegraciji mladih u Dubravi te ga objavili kao tri rada u jednome broju časopisa Migracijske teme (1998). Švob, Brčić i Podgorelec (1998) u uvodnom radu iznose demografsku analizu stanovništva Dubrave u međupopisnom razdoblju 1981. - 1991. Autorice su osobito razradile obilježja starosjedilačkoga stanovništva te onoga doseljenoga prema fazama migracija. Potom je provedeno pilot-istraživanje (anketa) na uzorku od dvjesto učenika osnovnih i srednjih škola, kako bi se dobili podaci o stavovima koji uključuju vezanost uz Dubravu, percepciju socijalnih razlika, životnu situaciju, provođenje slobodnog

skupine u Dubravi, Brčić i Čaldarović (1998: 68) navode Janjevce, Hercegovce, Bosance, Rome i sl. U radu smo za Janjevce odlučili upotrebljavati pojam etničke grupe, ne zbog različitoga etničkog podrijetla, već ponajprije zbog kulturnih, jezičnih i tradicijskih karakteristika po kojima se razlikuju od ostalih pripadnika većinskoga domicilnoga hrvatskoga etničkoga korpusa u Dubravi. Smatramo da je upravo ta kulturna i tradicijska posebnost razlog specifičnosti kulturnog pejzaža koji stvaraju u odnosu na pejzaže Dubrave u kojima Janjevci nisu grupirani u većoj mjeri. 
vremena i sl. Analizu podataka iznijeli su u sljedećem radu Katunarić, Podgorelec i Švob (1998). Na kraju su Brčić i Čaldarović (1998) interpretirali dobivene podatke koji upućuju na odnos među skupinama mladih, njihov odnos prema socijalnim i srodnim ustanovama te njihove želje i perspektive.

Polazišta ovoga rada bila su i istraživanja nekoliko autora koji su s povijesnoga i geografskog aspekta proučavali Dubravu: povjesničarka Vanda Ladović, s jednim od najranijih tekstova o povijesnom razvoju Dubrave (1960), geograf Ivan Crkvenčić (1968), koji je Dubravu stavio u kontekst drugih rubnih dijelova Zagreba, i geograf Ilija Globarević (1974), čija su tema magisterija bili problemi demografskoga i socioekonomskog razvoja Dubrave. Veći dio rada oslanja se na rezultate ankete provedene na devetsto roditelja osnovnoškolaca povjesničara Krešimira Kvočića, koji je prilozima u novinskom listu Dubrava - list radnih ljudi i građana općine Dubrava-Zagreb dao iznimno vrijedan uvid u trenutačno stanje društvenih i kulturnih događanja te komunalne infrastrukture i izgradnje Dubrave. Glavni statistički izvori bili su popisi stanovništva od 1857. do 2011., s detaljnijom analizom demografskih pokazatelja na razini statističkih krugova 2001.

\section{OSNOVNA DEMOGRAFSKA OBILJEŽJA DUBRAVE}

Pojedina razdoblja naseljavanja Dubrave i širenja njezine morfološke strukture, za koju je karakteristična intenzivna promjena kulturnoga pejzaža na nekada neizgrađenu zemljištu, bila su obilježena slabijim ili jačim porastom broja stanovnika. Sveukupno gledajući, do Drugoga svjetskog rata broj stanovnika veoma se sporo povećavao te je uvelike ovisio o broju stanovnika dubravačkih sela. Naime središte buduće općine, Zagrebačka (tada Granešinska) Dubrava, do 1931. bilježilo je samo 84 stanovnika. $^{2}$ No upravo je ona postala novim središtem Dubrave, prema kojemu su počela gravitirati sva okolna sela, a time i glavnim generatorom broja stanovnika u poslijeratnom razdoblju. Njezin se broj u sljedećih sedamnaest godina povećao za 53 puta (1948. godine 4439 stanovnika), a od 1948. do 1971. gotovo za devet puta (Korenčić, 1979: 769).

Zagrebačka se Dubrava ipak vidljivo razlikovala od ostalih naselja svoje bivše općine. Od svojega osnutka nije imala poljoprivredni karakter, a stambeni fond bio je privatno vlasništvo, što ju je izjednačivalo s okolnim selima, a razlikovalo od grada (Globarević, 1974: 13). Tako je primjerice 1971. na području današnje Dubrave sedam naselja bilo seoskoga tipa, osam mješovitoga, a ostalo je bila općina Dubrava (Korenčić, 1979: 773).

U popisu naselja Zagrebačka se Dubrava pojavila tek 1842. i imala samo devet stanovnika (Ladović, 1960: 304). Od 1850. do 1931. broj stanovnika tadašnje Granešinske Dubrave varira između četrnaest i 84 (Globarević, 1974: 17; Korenčić, 1979: 771). Tek se od 1948. Zagrebačka Dubrava izdvaja kao zasebno naselje s čak 4439 stanovnika (Korenčić, 1979: 769). 
Tablica1: Kretanje broja stanovnika Dubrave 1948. - 2011.

Table 1: Population trends in Dubrava, 1948 - 2011

\begin{tabular}{cccccc}
\hline Godina & $\begin{array}{c}\text { Broj } \\
\text { stanovnika }\end{array}$ & $\begin{array}{c}\text { Lančani } \\
\text { indeks }\end{array}$ & $\begin{array}{c}\text { Međupopisna } \\
\text { promjena }\end{array}$ & $\begin{array}{c}\text { Prosječna } \\
\text { godišnja } \\
\text { promjena } \\
\text { broja } \\
\text { stanovnika }\end{array}$ & $\begin{array}{c}\text { Stopa } \\
\text { prosječne } \\
\text { godišnje } \\
\text { promjene } \\
(\%)\end{array}$ \\
\hline 1948. & 12.827 & - & - & - & - \\
\hline 1953. & 14.454 & 112,7 & 1.627 & 325,4 & 2,4 \\
\hline 1961. & 27.369 & 189,4 & 12.915 & $1.614,40$ & 7,7 \\
\hline 1971. & 62.399 & 228 & 35.030 & $3.503,00$ & 7,8 \\
\hline 1981. & 81.720 & 131 & 19.321 & $1.932,10$ & 2,7 \\
\hline 1991. & 86.241 & 105,5 & 4.521 & 452,1 & 0,5 \\
\hline 2001. & 97.332 & 112,9 & 11.091 & $1.109,10$ & 1,2 \\
\hline 2011. & 98.204 & 100,9 & 872 & 87,2 & 0,1 \\
\hline
\end{tabular}

Izvori: Popisi stanovništva 1948., 1961., 1981. i 2001.; Korenčić, 1979; CD-ROM: Naselja i stanovništvo Republike Hrvatske 1857-2001, 2005; Popis stanovništva 2011., DZS, Zagreb

Nakon Drugoga svjetskoga rata stanovništvo Dubrave naglo je poraslo. Premda je porast od 1953. do 1961. bio izniman (lančani je indeks 189), najveći porast broja stanovnika Dubrave zabilježen je u međupopisju 1961. - 1971., na što upućuju pokazatelji u tablici 1 (lančani je indeks 228, a međupopisna promjena čak 35.030 stanovnika). Ipak, prosječna godišnja promjena stanovnika po stopi od gotovo osam posto godišnje obilježila je i prethodno međupopisno razdoblje, što navodi na zaključak da je najjači populacijski bum Dubrava doživjela od pedesetih do sedamdesetih godina 20. stoljeća. Osim Zagrebačke Dubrave, koja je u šezdesetima povećala broj stanovnika za dva i pol puta, na tako nagli porast stanovništva utjecalo je i bujanje Retkovca, preciznije Novoga Retkovca ${ }^{3}$ i Trnave Resničke. Tako su 1971. populacijski najveći dijelovi Dubrave bili Zagrebačka Dubrava, Trnava Resnička i Retkovec, koji su zajedno činili 84\% ukupnoga stanovništva Dubrave. Porast stanovništva zabilježila su i naselja uz veće prometnice (Granešina, Miroševec, Oporovec i Čulinec) (Korenčić, 1979: 766, 769).

3 Popis iz 1971. bilježi naselje Retkovec, a 1981. mjesne zajednice Novi Retkovec i Stari Retkovec. Porast stanovništva u najvećem se dijelu odnosi na Novi Retkovec, novo stambeno naselje izgrađeno nakon poplave Save 1964. 
Prema popisu stanovništva iz 1981., po više od pet tisuća stanovnika živjelo je u mjesnim zajednicama smještenima na područjima koja su šezdesetih i sedamdesetih prihvatila veliki dio stanovnika u novoizgrađene stambene zgrade (npr. Studentski grad), zatim na području tzv. Janekovićeve parcelacije sjeverno od Ulice Dubrava (Franjo Kluz) te u dominantno neplanskim naseljima Donje Dubrave (primjerice Tomše Martin). Takav se populacijski razvoj podudara s razdobljem najjačega širenja morfološke strukture u tom dijelu Dubrave (Crljenko, 2012a: 128-133).

Trend porasta stanovništva znatno se usporio osamdesetih, pa se u demografskome smislu u međupopisju 1981. - 1991. Dubrava povećala za »samo« 4521 stanovnika. Devedesetih godina 20. stoljeća međupopisna se promjena opet u znatnijoj mjeri povećala (za oko tri puta u odnosu na prošlo razdoblje), što valja povezati s povećanim imigracijama prognanika, izbjeglica i janjevačkog stanovništva kao posljedicom Domovinskoga rata. Očekivano, posljednje je međupopisno razdoblje pokazalo vrlo blagi trend porasta broja stanovnika jer su se smanjile poslijeratne migracije.

Povećanje ukupnoga broja stanovnika Dubrave nije se jednakomjerno odrazilo u prostoru. Osim o osnovnoj konfiguraciji terena i drugim prirodnogeografskim obilježjima gustoća stanovništva ovisi i o mnogim društvenim čimbenicima (udjelu već izgrađenog zemljišta, /ne/pridržavanju planske regulative, postojanju ili nepostojanju te regulative, namjeni iskorištavanja zemljišta, razmještaju i koncentraciji gospodarskih djelatnosti i dr.).

Prema popisu iz 2001., u gradskoj četvrti Gornja Dubrava 4 živi 61.388 stanovnika, tj. 1,7 puta više nego u Donjoj Dubravi (35.944), dok je omjer njihovih površina $4: 1 .^{5}$ Iz toga proizlazi da je gustoća naseljenosti veća u Donjoj Dubravi (3325 st./ $\mathrm{km}^{2}$ ) nego u Gornjoj Dubravi (1524 st. $/ \mathrm{km}^{2}$ ). Najgušće su naseljeni područje Donje Dubrave neposredno uz Ulicu Dubrava, s 10.072 st. $/ \mathrm{km}^{2}$, zapadni dio Donje Dubrave te južni dio Gornje Dubrave (sl. 1). Vrlo općenito uzevši, riječ je o području između Avenije G. Šuška na zapadu, groblja Miroševca i potoka Trnave na sjeveru, istočnih dijelova Trnovčice, Dupca i Novoga Retkovca na istoku te Čulinca i srednjega dijela Trnave na jugu - području koje se uvjetno može nazvati »užom«, kompaktno izgrađenom Dubravom, a prostire se na oko dvanaest četvornih kilometara. To je ujedno i onaj dio koji mnogi Dubravčani, kao i oni koji žive izvan Dubrave, najčešće perceptivno poistovjećuju s pojmom Dubrave. Očekivano, najrjeđe su naseljeni sjeverni i sjeveroistočni dijelovi Dubrave, gdje su velike površine pod šumama i poljima te raštrkana malena depopulirana sela, kao i krajnji jugoistočni,

4 Dubrava je 1999. podijeljena na dvije gradske četvrti: Gornja i Donja Dubrava (prema Statutu grada Zagreba).

5 Popis 2011. bilježi 61.841 stanovnika u Gornjoj, odnosno 36.363 u Donjoj Dubravi i isti omjer broja stanovnika od 1,7. 
gotovo neizgrađen dio. Promatrajući takav razmještaj stanovništva sa stajališta izgradnje stambenoga fonda, a time i promjena kulturnog pejzaža, zanimljivo je da bez obzira na veći udio visoke stambene gradnje u Gornjoj Dubravi, u dominantno niskoj stambenoj gradnji u Donjoj Dubravi živi gotovo dvostruko više stanovnika na jedinici površine, što je izravna posljedica mahom neplanske, zbijene gradnje (Crljenko, 2012b: 31-32).

Posljedice naglog povećanja broja stanovnika od Drugoga svjetskog rata do osamdesetih godina vidljive su u današnjemu kulturnom pejzažu Dubrave u morfološkim promjenama mnogih njegovih elemenata (Crljenko, 2012a: 129-130). Vjerojatno najizrazitija manifestacija jest nagla (i često neplanska) izgradnja i povećanje stambenoga fonda, najviše u dijelu »uže« Dubrave (sl. 2). Tako su primjerice u tridesetak godina, od početka gradnje Studentskoga grada (početak 1949.) i Klake, neizgrađeni dijelovi Dubrave dobili više desetaka visokih stambenih zgrada s uređenom okolicom, potrebnim i zadovoljavajućim društvenim i komunalnim sadržajima (vrtići, škole, trgovine, asfaltirane ceste, vodovod, kanalizacija i dr.). S druge strane, prostrana područja neplanske gradnje, poglavito u Donjoj Dubravi, bila su u to vrijeme obilježena manjkom takvih sadržaja, ali s preizgrađenim zemljišnim parcelama u gotovo isključivo stambene svrhe bez okućnice ili s vrlo malenom okućnicom, s dograđenim objektima neprilična izgleda i oblika. Premda su se neki obrti poput gostionica i trgovina širili od samog početka naseljavanja Dubrave, dakle od četrdesetih godina 20. stoljeća (Strukić i Antoš, 2012: 67), njihova brojnost i specijaliziranost povećale su se u kasnijim razdobljima, pa je Dubrava u početku bila samo jedna velika gradska »spavaonica«. 
Slika 1: Gustoća stanovništva Dubrave 2001. po statističkim krugovima

Figure 1: Population density of Dubrava in 2001 by statistical circles

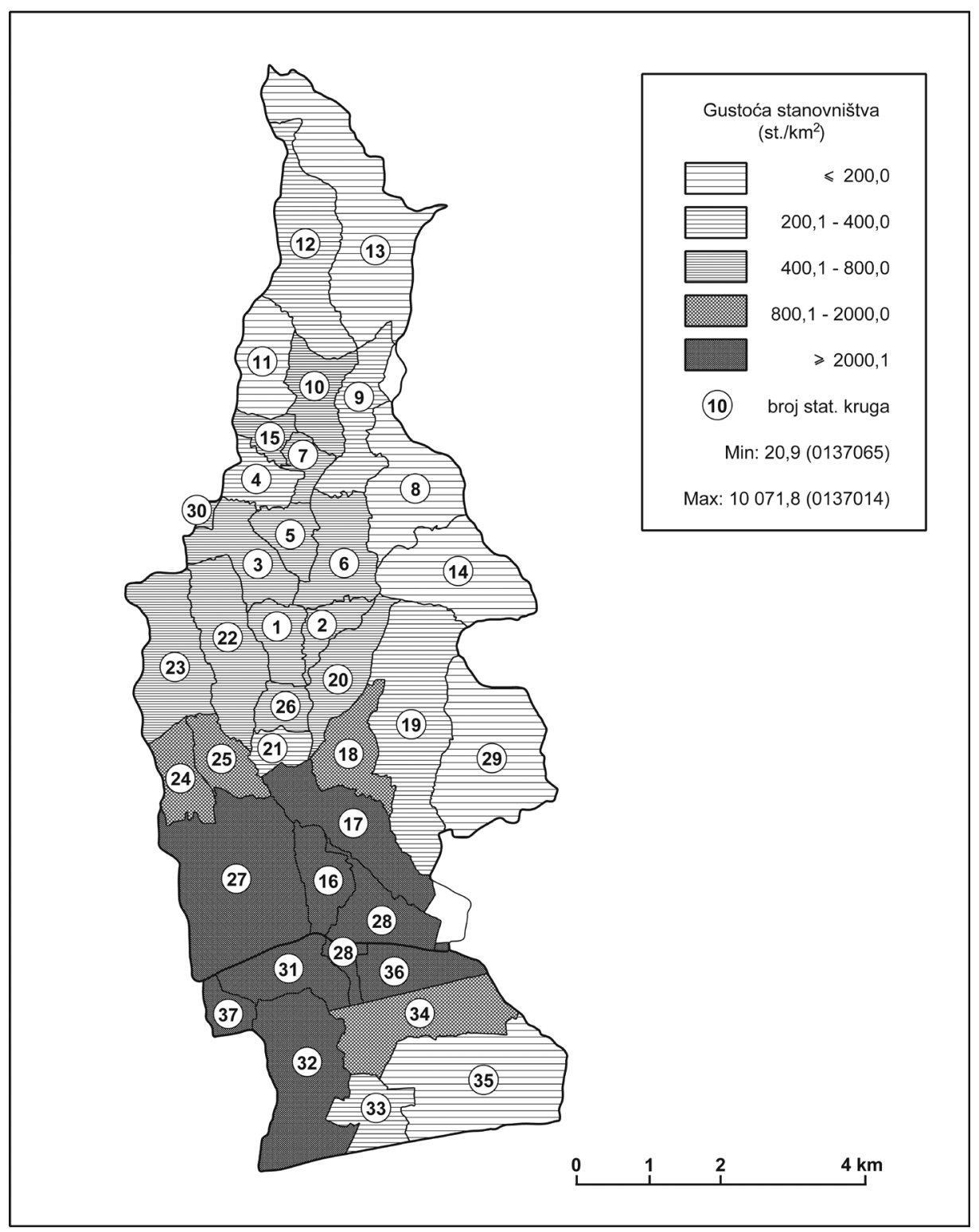

Izvor: Popis stanovništva, kućanstava i stanova 2001., Državni zavod za statistiku, posebno obradene tablice 
Slika 2: Gustoća stanova 2001. po statističkim krugovima

Figure 2: Housing density in 2001 by statistical circles

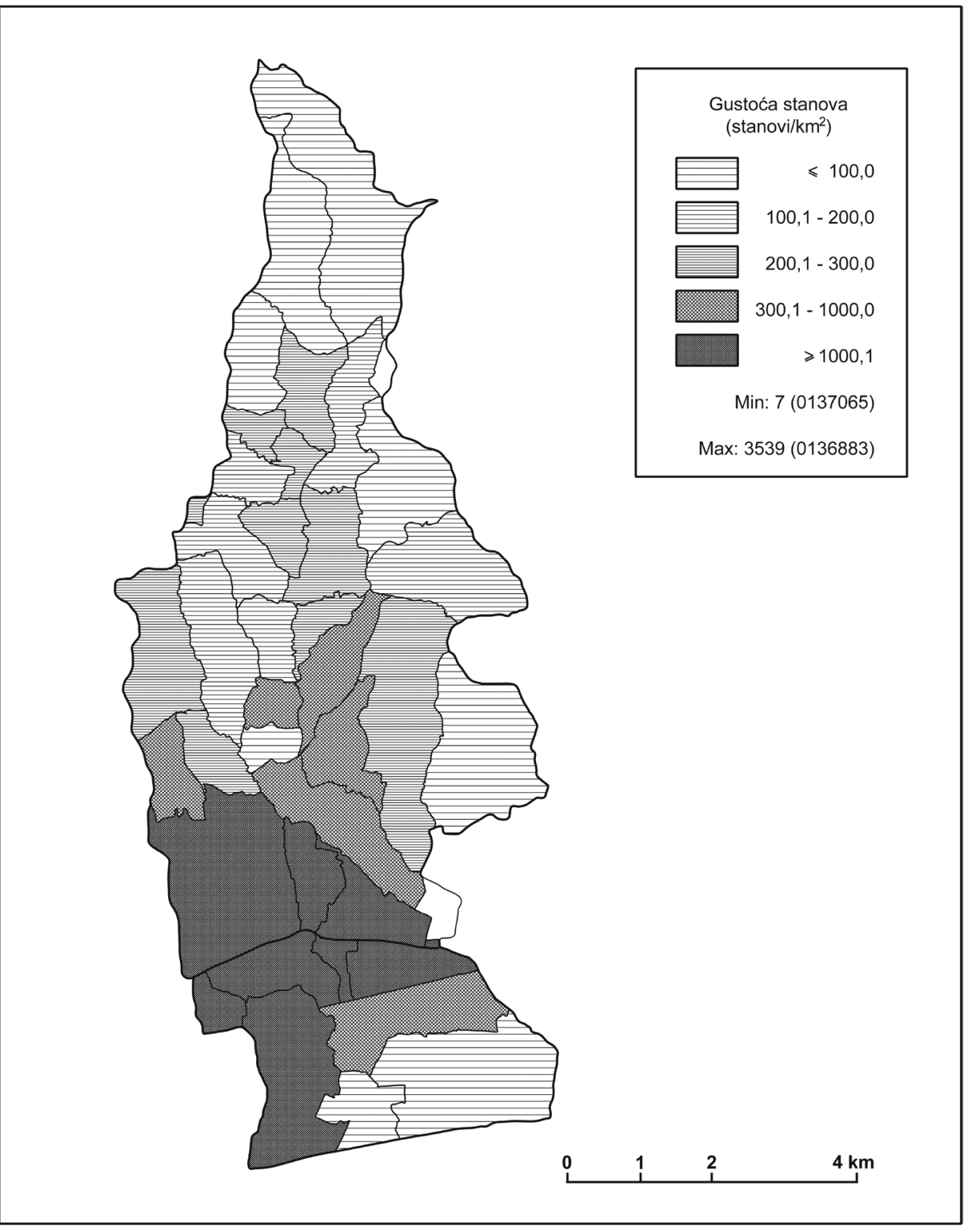

Izvor: Popis stanovništva, kućanstava i stanova 2001., Državni zavod za statistiku, posebno obrađene tablice 
Popisom 2001. u Dubravi je zabilježeno 35.378 stanova. Gotovo se dvije trećine svih stanova $(65,6 \%)$ nalaze u Gornjoj Dubravi, što se dobro uočava na slici 2. Broj stanova u odnosu na površinu statističkoga kruga upućuje na glavne pravce širenja Dubrave (prema sjeveru i jugu) i, s druge strane, na područja s većim udjelom šuma, s teže pristupačnim terenom, oranična ili neiskorištena područja te područja posebnih funkcija i zabranjene izgradnje (npr. Grad mladih), gdje je gustoća stanova najmanja. Broj stanova za stalno stanovanje u dvadeset godina povećao se za 47,5\% u odnosu na 1981. Razlog tako velikom porastu broja stanova jest izgradnja velikih stambenih zgrada u Novome Retkovcu i Poljanicama osamdesetih i devedesetih te širenje zona individualne izgradnje u Trnavi, Oporovcu, Granešini i drugdje. ${ }^{6}$ Ipak, najveći broj stanova izgrađen je prije osamdesetih, između 1961. i 1970. (Kvočić, 1984: 5).

\section{DOSELJAVANJE U DUBRAVU}

Najvažniji čimbenik porasta broja stanovnika intenzivno je doseljavanje u Dubravu, ${ }^{7}$ što je rezultiralo njezinim morfološkim širenjem od zapada prema istoku. Udio je doseljenika u ukupnom stanovništvu dviju dubravačkih gradskih četvrti 2001. godine oko 50\% (Donja Dubrava 53,1\%, Gornja 50,8\%). Globarević (1974: 21) iznosi podatke o migracijskim obilježjima prema kojima su 1971 . godine $67 \%$ stanovnika tadašnje Dubrave bili doseljenici. Najveći udio imigranata imala su naselja Novaki Granešinski, Oporovec, Granešina, Jalševec, Čučerje, Trstenik, Miroševec, Degidovec te Zagrebačka Dubrava, u kojoj su 1971. godine 70\% bili doseljenici, a samo ih je 30\% rođeno u Dubravi. Popis 1981. bilježi da je na području Dubrave 65\% doseljenih (Švob, Brčić i Podgorelec, 1998: 17), a popis iz 2001. registrira $56 \%$ doseljenih. Razumljivo je da je udio doseljenika bio veći u ranijem razdoblju, kada je Dubrava bila prava periferija doseljeničkoga tipa. ${ }^{8}$

Unatoč smanjenju udjela doseljenih u novijem razdoblju i činjenici da je ni statistički više ne možemo smatrati područjem doseljeničkoga tipa, svijest o Dubravi kao izrazito imigracijskoj zagrebačkoj periferiji prisutna je i dalje ne samo kod njezinih stanovnika nego, čini se, još i više kod stanovnika ostalih dijelova Zagreba.

U srednjoročnome planu razvoja Zagreba 1975. - 1980. Dubrava je definirana kao jedan od glavnih razvojnih pravaca grada. Tim je planom predviđeno da će se do 1980. u Dubravi izgraditi 10.270 stanova, a u 1981. još 9700 (list Dubrava, br. 1/1978, str. 5). Ipak, da su planovi jedno, a realizacija nešto drugo, govori analiza učinjenoga u tom razdoblju, prema kojoj je izgrađeno manje stanova u društveno usmjerenoj stambenoj izgradnji, ali je taj manjak nadoknadila, čak i premašila, individualna gradnja (list Dubrava, pos. br. 29/1980, str. 6, 7).

7 Da su migracije ključni generator povećanja broja stanovnika, potvrđuje i činjenica da je u općini Dubrava broj stanovnika u međupopisju 1953. - 1961. porastao za 89,3\%, od čega $12,7 \%$ prirodnom promjenom, a 76,6\% pozitivnim migracijskim saldom (Crkvenčić, 1968: 255).

8 Prema Nejašmiću (1994: 7), neko je područje »doseljeničkoga tipa« ako mu je donja granica udjela doseljenika u ukupnome stanovništvu 66,6\% ili, prema labavijem kriteriju, 51\%. 
Mnogi će Zagrepčani stoga reći da je to naselje u kojem su ljudi došli »od svugdje $\ll$, a oni stariji mogu se prisjetiti poznate krilatice o Dubravi kao »Jugoslaviji u malom«. Smanjenje udjela doseljenika u odnosu na stanovništvo rođeno u Dubravi svakako je rezultat njezine dugovječnosti, koja se danas broji u desecima godina (preciznije oko osamdeset godina od prvih parcelacija zemljišta i početaka izgradnje »uže« Dubrave tridesetih godina 20. stoljeća) u njezinu kompaktno izgrađenom dijelu, tijekom kojih se stvorila značajna baza sada već starosjedilačkoga stanovništva (Crljenko, 2012b: 33-34).

Razmještaj doseljenika vidljiv na slici 3 jasno upućuje na dijelove intenzivnijega doseljavanja (»uža« Dubrava) i područja slabijega doseljavanja (sjeverni, sjeveroistočni i jugoistočni dijelovi), koja su zbog veće udaljenosti od grada, slabije prometne dostupnosti, lošije infrastrukture, skupljega zemljišta i nepogodnijega terena manje atraktivna za masovnije naseljavanje. Zanimljivo je ipak da se, uz kompaktno izgrađeni dio Dubrave, prema udjelu doseljenika ističu i dijelovi Oporovca, Novoselca i Granešine, koji se intenzivnije naseljavaju već u ranijim razdobljima, što je posljedica bolje prometne dostupnosti i jeftinijeg zemljišta. Valja ipak očekivati da će se zbog izgrađenosti središnjega dijela Dubrave budući doseljenici u većoj mjeri naseljavati i u predjele sjeverne i jugoistočne Dubrave (o čemu svjedoče porast vikendaša koji preseljenjem u nekadašnje vikendice postaju stalni stanovnici te izgradnja tzv. urbanih vila na atraktivnome prigorskom području). Može se zaključiti da je distribucija doseljenika u Dubravi logična te potvrđuje činjenicu da doseljavanje prati razvoj morfološke strukture, odnosno usku povezanost tih dvaju procesa.

Dinamika doseljavanja u Dubravu nije bila pravocrtna i podudara se s intenzivnijom izgradnjom dijelova Dubrave u određenome razdoblju. Prema intenzitetu imigracija, mogu se izdvojiti razdoblja jačega i slabijega doseljavanja, konkretnije dva imigracijska vala: prvi, od 1946. do 1980. s vrhuncem u šezdesetima, i drugi, nešto slabiji, od 1991. do 2001., povezan s ratnim zbivanjima u Hrvatskoj (sl. 4). O prvome imigracijskom valu Globarević (1974: 25) na temelju popisa iz 1971. kaže da je vrhunac doseljavanja bio od 1953. do 1965., kada je općenito bila najjača imigracija u Zagreb. Tada se u vlastite kuće u Dubravi doselilo 44,1\% doseljenika. Od 1966. do 1970. imigriralo je 35,1\% doseljenika, a valja reći da se ranije naseljavala Gornja Dubrava.

Prema popisu iz 2001., od ukupno doseljenih u Gornju Dubravu (31.173) u prvom je valu imigrirala polovina svih doseljenih $(55,4 \%)$, a od 1991. do 2001. gotovo trećina svih doseljenih (26,9\%). Od ukupno doseljenih (19.088) u dvama je najjačim valovima doseljavanja u Donju Dubravu imigriralo 57,4\% u prvome valu, kada se cijeli Zagreb industrijski i urbanistički snažno razvijao, i 27,3\% u drugome valu. 
Slika 3: Odnos doseljenoga i ukupnoga stanovništva 2001. po statističkim krugovima

Figre 3: The ratio of immigrants and the total population in 2001 by statistical circles

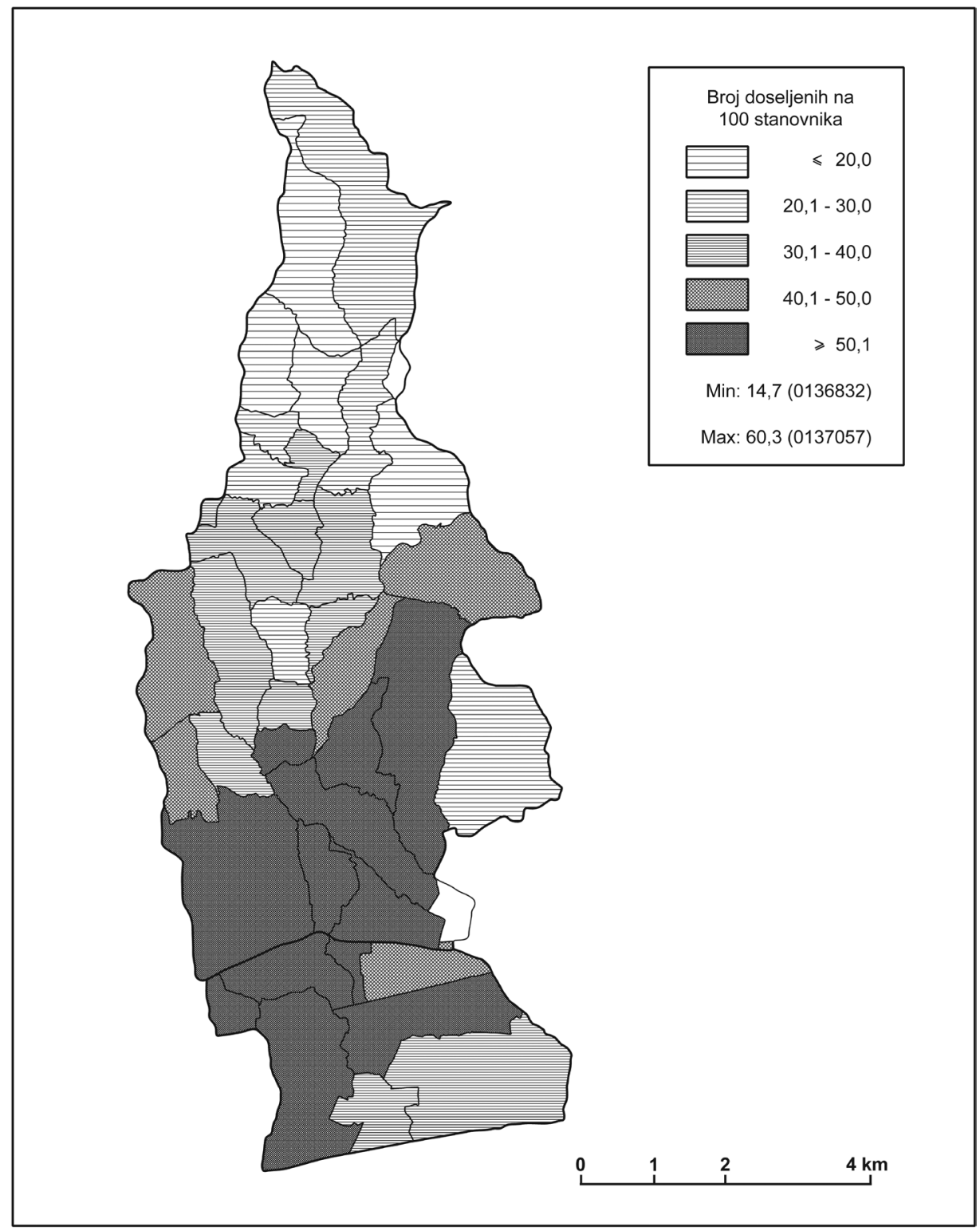

Izvor: Popis stanovništva, kućanstava i stanova 2001., Državni zavod za statistiku, posebno obrađene tablice 
Slika 4: Stanovništvo Gornje i Donje Dubrave prema razdobljima doseljavanja

Figure 4: The population of Gornja and Donja Dubrava by periods of immigration

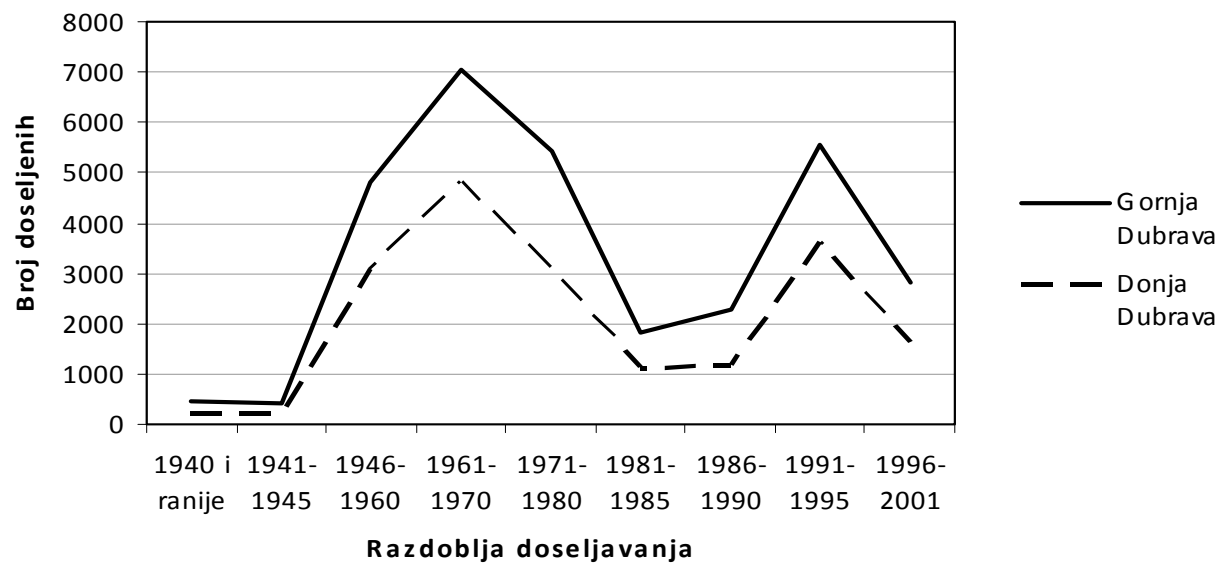

Izvor: Popis stanovništva, kućanstava i stanova 2001., Državni zavod za statistiku, posebno obrađene tablice

Usporedbom razmještaja doseljenika u dvama migracijskim valovima uočava se da su smjerovi migracija u oba vala bili gotovo identični, što znači da se stanovništvo uglavnom naseljavalo u iste statističke krugove (usporedi slike 1 i 5). Dakle područja koja su bila atraktivna za naseljavanje takvima su i ostala. To su ponajprije područja današnjih mjesnih odbora Dubrava-središte, Gornja Dubrava, Klaka, Studentski grad, Poljanice, Trnovčica, Dubec te gotovo cijela Donja Dubrava, osim Resničkoga Gaja i južnoga dijela Trnave. Ipak, u područja Oporovca, Novoselca i Staroga Retkovca doseljeno je više ljudi nakon Domovinskoga rata nego u 35 godina (1946. - 1980.) najjače migracije stanovnika u Dubravu. Pojačane migracije, ponajviše u područja oko Južne ulice, Klake sjeverno od Oporovečke ulice i Oporovca, valja povezati s najnovijim valom doseljavanja Janjevaca nakon 1992., dok su se ostali dijelovi, koji su naseljeni i izgrađeni u posljednjih dvadesetak godina, popunili uglavnom izbjeglicama iz $\mathrm{BiH}$. Može se pretpostaviti da će ti dijelovi Dubrave, zbog još neizgrađenog zemljišta, ostati atraktivni. Takav se prostorni razmještaj doseljenika u velikoj mjeri podudara s razmještajem svih stanovnika. 
Slika 5: Odnos broja doseljenika u dva vršna razdoblja doseljavanja (1946. 1980. i 1991. - 2001.)

Figure 5: The ratio of the number of immigrants in two peak periods of immigration (1946 - 1980 and 1991 - 2001)

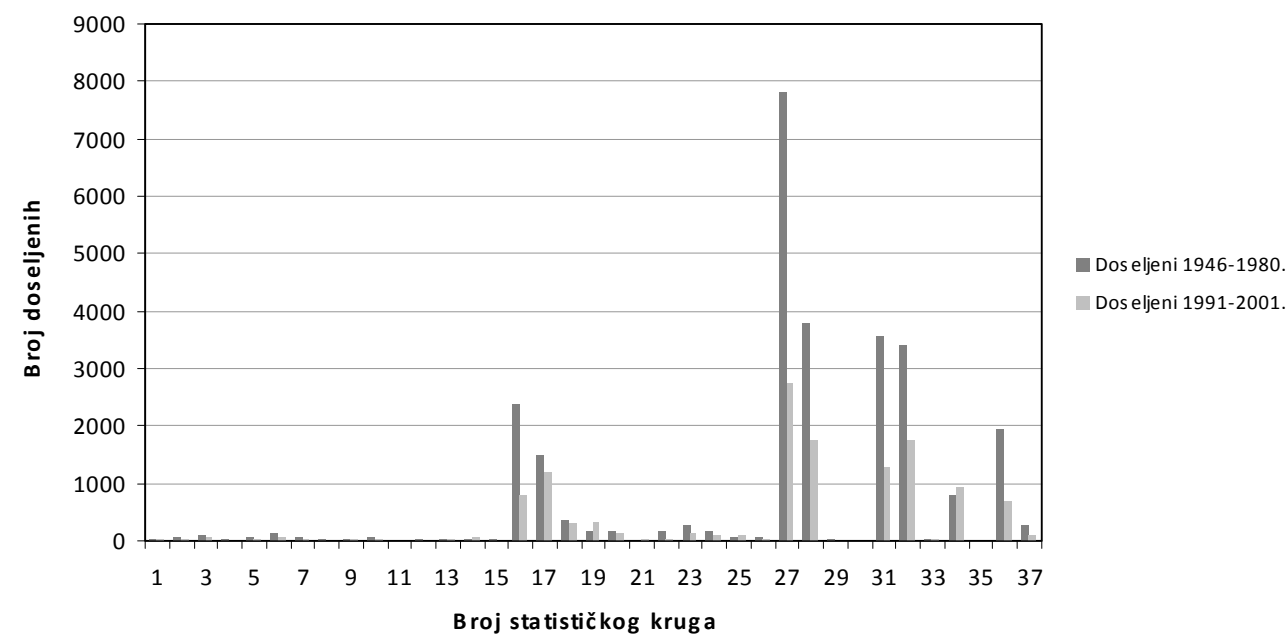

Izvor: Popis stanovništva, kućanstava i stanova 2001., Državni zavod za statistiku, posebno obrađene tablice

Osnovni motivi naseljavanja već su istaknuti. Dubrava je, osobito u razdoblju prvoga jačeg naseljavanja, bila neizgrađeno područje na rubu velikoga grada u ekonomskom uzletu, koji je imao veliku potrebu za radnom snagom, pa je nudio zaposlenje, prostor za život i obrazovanje te bolju perspektivu uspjeha. Zemljište u Dubravi bilo je jeftino i dostupno pretežno radničkome i seoskom stanovništvu, koje je u to doba bilo zahvaćeno snažnim procesima deagrarizacije i egzodusa iz ruralnih područja Hrvatske (Crkvenčić, 1968: 259; Globarević, 1974: 37-40). Osim dovoljno velikih i ravnih površina to je bilo područje čistoga zraka s Medvednice i velikih količina vode temeljnice, a na nekim se parcelama pijesak i šljunak nalaze neposredno ispod površine, što je smanjivalo troškove gradnje. Nadalje, izgradnjom tramvajske pruge 1942. osigurana je prometna povezanost prostora s gradom (Globarević, 1974: 19). Nepostojanje zakonske i planske regulative koja bi kontrolirala ili ograničila doseljavanje te postojanje rođačkih i prijateljskih veza između novijih i starijih doseljenika u Dubravu bili su dodatni motivi za naseljavanje upravo tamo. 
Stanovništvo, uglavnom mlađe, bilo je nižeg obrazovanja i socijalnog statusa te mahom zaposleno u industriji i građevinarstvu. ${ }^{9}$ Osim toga bilo je sklono prenošenju tradicija, navika i životnoga stila iz svojih prvobitnih ruralnih sredina. Budući da imigranti prije nego što su se naselili u Dubravu nisu bili dnevni cirkulanti, nego su se izravno doselili iz ruralnih područja, nisu se mogli postupno prilagoditi gradskome načinu života, pa su sa sobom donijeli i u znatnoj mjeri još dugo zadržali navike i način života iz krajeva iz kojih su došli (Crkvenčić, 1968: 258; Globarević, 1974: 81), što je utjecalo i na fizionomiju doseljenog područja.

Vjerojatno se to najbolje očituje u činjenici da su ruralni doseljenici, premda su se preselili na gradsku periferiju, još uvijek bili povezani sa zemljom. Tako primjerice u Dubravi šezdesetih i sedamdesetih godina 20. stoljeća, a u Donjoj Dubravi i mnogo poslije, nije bilo neobično vidjeti kuću s objektom u kojem se držala stoka i perad, s vrtom ili poljem iza kuće. Globarević (1974: 81) ističe da je 24,6\% ispitanika ankete imalo kokošinjac, a 10,3\% svinjac. Osim toga veći broj djece u obitelji i želja da ona ostanu u roditeljskome domu, što je više obilježje ruralnoga načina života nego gradskoga, utjecali su na izgradnju velikih dvokatnica i trokatnica, bez obzira na to što infrastrukturno uređenje prostora nije pratilo takvu izgradnju, a ni djeca često nisu opravdala očekivanja roditelja i ostala u roditeljskome domu. Nadalje, znatni udio radnoga stanovništva bili su građevinski radnici i drugi NKV-, KV-, VKV-radnici (Globarević, 1974: 53), što se odrazilo u izgradnji vlastitih kuća (ali velikim dijelom i kuća susjedâ, rodbine i prijateljâ) prema načelu »sam svoj majstor«. Dakako da su neka građevinska rješenja nastala prema tom načelu, najblaže rečeno, estetski dvojbena.

Prema Švob, Brčić i Podgorelec (1998: 19), doseljenici su, uza starosjedilačko stanovništvo, jedna od društvenih skupina u Dubravi. Najčešće ih prepoznajemo po regionalnom podrijetlu (npr. Bosanci i Hercegovci u Dubravi podrijetlom su u najvećem broju etnički Hrvati iz BiH; Janjevci su Hrvati s Kosova). Švob, Brčić i Podgorelec (1998: 19-25) doseljenike su prema vremenu doseljavanja (bez obzira na to jesu li dotad stekli pravo na hrvatsko državljanstvo ili ne i ne uzimajući kao isključivi kriterij razdvajanja njihovo etnonacionalno podrijetlo) podijelili na: a) one koji su imigrirali nakon Drugoga svjetskoga rata, b) stanovništvo doseljeno nakon

9 Dobna i socioekonomska struktura slične su i danas. U Dubravi je nešto više mladoga stanovništva i manje staroga stanovništva u odnosu na druge dijelove Zagreba. Odnos mladoga i staroga stanovništva 2001. bio je 25 prema 17 posto, odnosno indeks starosti u Donjoj Dubravi bio je 62,2, a u Gornjoj Dubravi 71,1. U obrazovnom je smislu u Dubravi i danas znatno lošija struktura stanovništva nego u starijim gradskim četvrtima. Tako Donja Dubrava bilježi čak 37\%, a Gornja Dubrava 32\% stanovnika bez škole ili samo s osnovnom školom. U odnosu na pretežita zanimanja doseljenika današnja socioekonomska struktura Dubravčana razlikuje se od nekadašnje. Nekadašnja je Dubrava bila područje u kojem su radnici bili zaposleni uglavnom u industriji i građevinarstvu, a danas su uglavnom zaposleni u tercijarnim djelatnostima (Popis stanovništva 2001.; Crljenko, 2012b: 33, 38). 
1991. (izbjeglice, prognanici i novi doseljenici) i c) vanjsku migraciju te pripadnike manjina. ${ }^{10}$ Ta podjela, između ostaloga, upućuje na raznolikost podrijetla doseljenika, ali i njihovu važnost u razvoju i širenju Dubrave, kako u formiranju specifične zajednice u kojoj je koegzistencija etničke i nacionalne raznolikosti u svakodnevnom životu posve uobičajena tako i u oblikovanju njezina kulturnog pejzaža.

Upravo su migracijska obilježja u znatnoj mjeri odredila narodnosnu strukturu Dubravčana. Premda nacionalno izrazito homogeno (93,6\% Hrvati), stanovništvo Dubrave prema popisu iz 2001. čine i pripadnici manjina, od kojih su najzastupljeniji Srbi (1,7\% od ukupnog broja stanovnika Dubrave) i Bošnjaci (0,7\% od ukupnog broja Dubravčana), dok je Albanaca, Roma i drugih pripadnika manjina manje od $0,5 \%$, tj. nekoliko stotina.

Razmještaj pripadnika manjina upućuje na neke karakteristike migracija jer govori o tome odakle su došli pripadnici određenih manjina i kamo su se naseljavali unutar Dubrave. Kako se vidi na slici 6, područja sa znatnijim udjelom manjina dijelovi su središnje Dubrave, što govori u prilog činjenici da starosjedilačko stanovništvo prevladava u starim selima na sjeveru i jugu Dubrave.

Srba ima u svim dijelovima, osobito u područjima ranijega doseljavanja. Bošnjaci su zastupljeni u području oko željezničke pruge, tj. u njezinu najzapadnijem dijelu, Čulincu i Starome Retkovcu, Oporovcu i manje u Miroševcu, dakle i u područjima ranijega i u područjima kasnijega doseljavanja. Albanaca je više u Miroševcu i Oporovcu, dok je Roma najviše u Dupcu i Trnavi.

Osim pripadnika manjina na današnju morfologiju i fizionomiju Dubrave najviše su utjecali doseljenici nakon Drugoga svjetskoga rata te oni koji su se u Dubravi nastanili tijekom i nakon Domovinskoga rata, a mahom su Hrvati iz drugih dijelova države i BiH. Prema podacima Globarevićeve ankete (1974: 30), od 708 ispitanika koji su do 1974. došli iz Hrvatske, najviše ih je bilo iz Središnje Hrvatske, poglavito iz Hrvatskoga zagorja, Podravine, Međimurja te susjednih zagrebačkih općina (75,3\%), zatim iz Primorske Hrvatske (12,5\%) te Istočne Hrvatske (10,4\%). I popis 2001. govori tome u prilog. Najveće je doseljavanje zabilježeno iz ostalih hrvatskih županija (55,87\%), poglavito iz Slavonije, Bjelovarsko-bilogorskoga kraja, Hrvatskog zagorja i Like. ${ }^{11}$ To se može povezati s položajem Dubrave na istočnom ulazu u Zagreb, koji je mnogim doseljenicima iz navedenih područja najbliži prvobitnom prebivalištu, kao i s već spomenutim jeftinijim, dotad neizgrađenim zemljištem te vezama s prije doseljenim stanovnicima podrijetlom iz istoga kraja (tablica 2).

10 Više o razdobljima doseljavanja imigranata u Dubravu, o njihovim obilježjima i područjima pretežitog okupljanja tih dviju skupina vidi u Švob, Brčić i Podgorelec (1998: 19-25).

11 Budući da podaci o broju doseljenih iz pojedine županije nisu dostupni u službenoj statistici, nego su svrstani u zajedničku kategoriju »doseljeni iz druge županije«, ovakva se tvrdnja temelji na vlastitom poznavanju stanja u Dubravi i razgovoru s nekolicinom njezinih stanovnika. 
Slika 6: Razmještaj manjina u Dubravi 2001. (SK = statistički krug)

Figure 6: Population distribution in Dubrava, 2001 (SK = statistical circle)

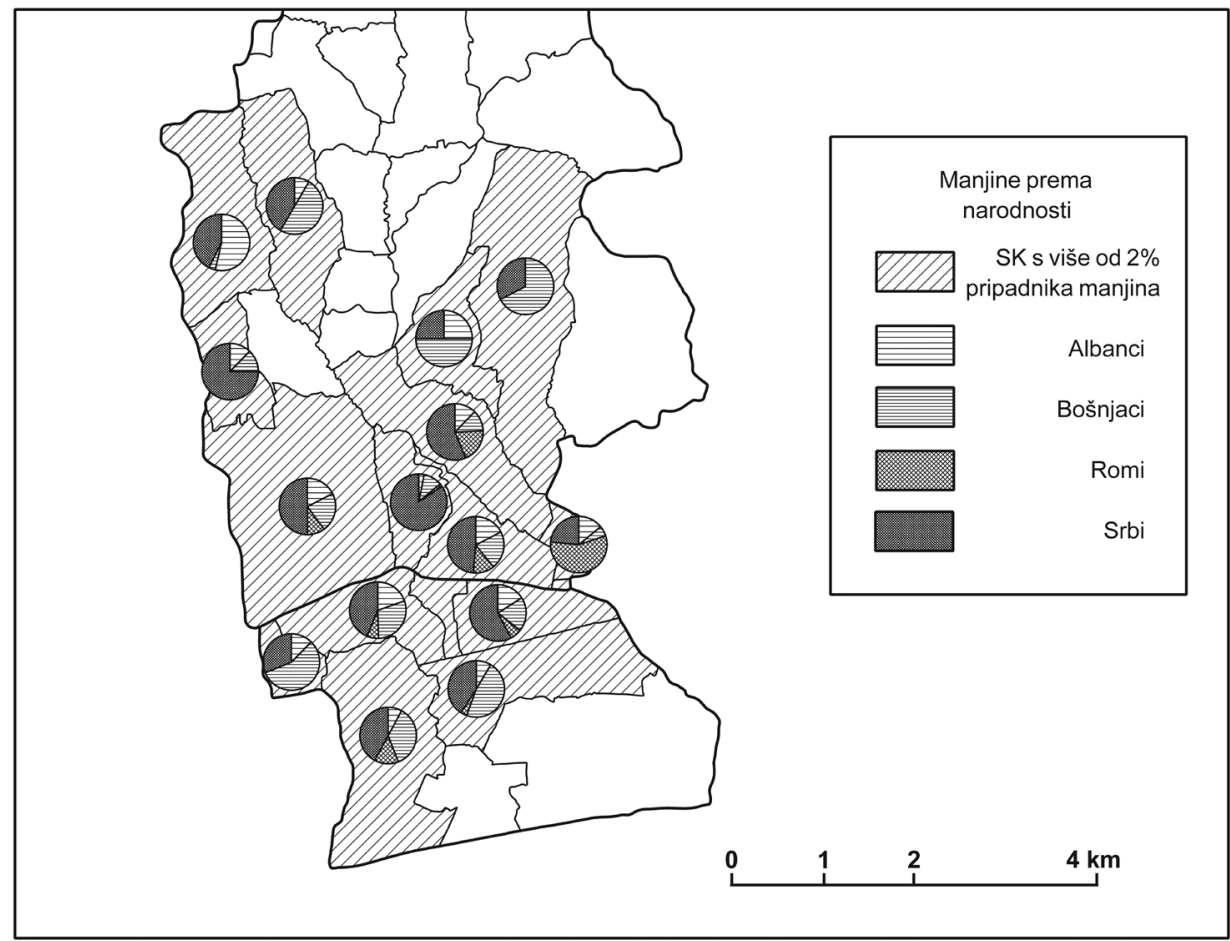

Izvor: Popis stanovništva, kućanstava i stanova 2001., Državni zavod za statistiku, posebno obrađene tablice

Drugu najveću skupinu doseljenika čine oni iz inozemstva, s udjelom u ukupnome broju doseljenih od otprilike 40\%. Udio je nešto veći u Donjoj Dubravi (42,9\%). Najveći broj inozemnih imigranata u Dubravu se doselio iz BiH i bivše SRJ, ${ }^{12}$ što je očito iz podatka prema kojemu je broj imigranata iz BiH u odnosu na ukupno doseljeno stanovništvo iz inozemstva u Dubravi 70,2\%. Sljedeća je veća skupina

12 Službena popisna statistika evidentira broj doseljenika iz BiH i bivše SRJ, ali ne i njihovo etnonacionalno podrijetlo. Stoga nije moguće precizno razdvojiti broj doseljenika iz BiH i bivše SRJ prema podrijetlu. Na temelju postojećih podataka može se tek govoriti o njihovoj ukupnoj zastupljenosti. Globarević (1974: 27) ističe da o priličnome broju imigranata iz BiH govori podatak da u Dubravi znatan broj ulica nosi bošnjačka imena (najviše po gradovima u BiH, op. a.). Nadalje, popisom ne samo da nije zabilježeno iz kojega su dijela BiH dolazili doseljenici u Dubravu (npr. iz kojih općina u BiH), što bi moglo uputiti na to koje su narodnosti ili etničke pripadnosti, nego ni u koje su se dijelove Dubrave pojedini doseljenici (bosanski Hrvati i Srbi te Bošnjaci) naseljavali. Zato se zaključci o tome koje dijelove Dubrave naseljavaju koji doseljenici nužno izvode na temelju razgovora s Dubravčanima i drugim dobrim poznavateljima prostora, novinskih članaka i drugih izvora. 

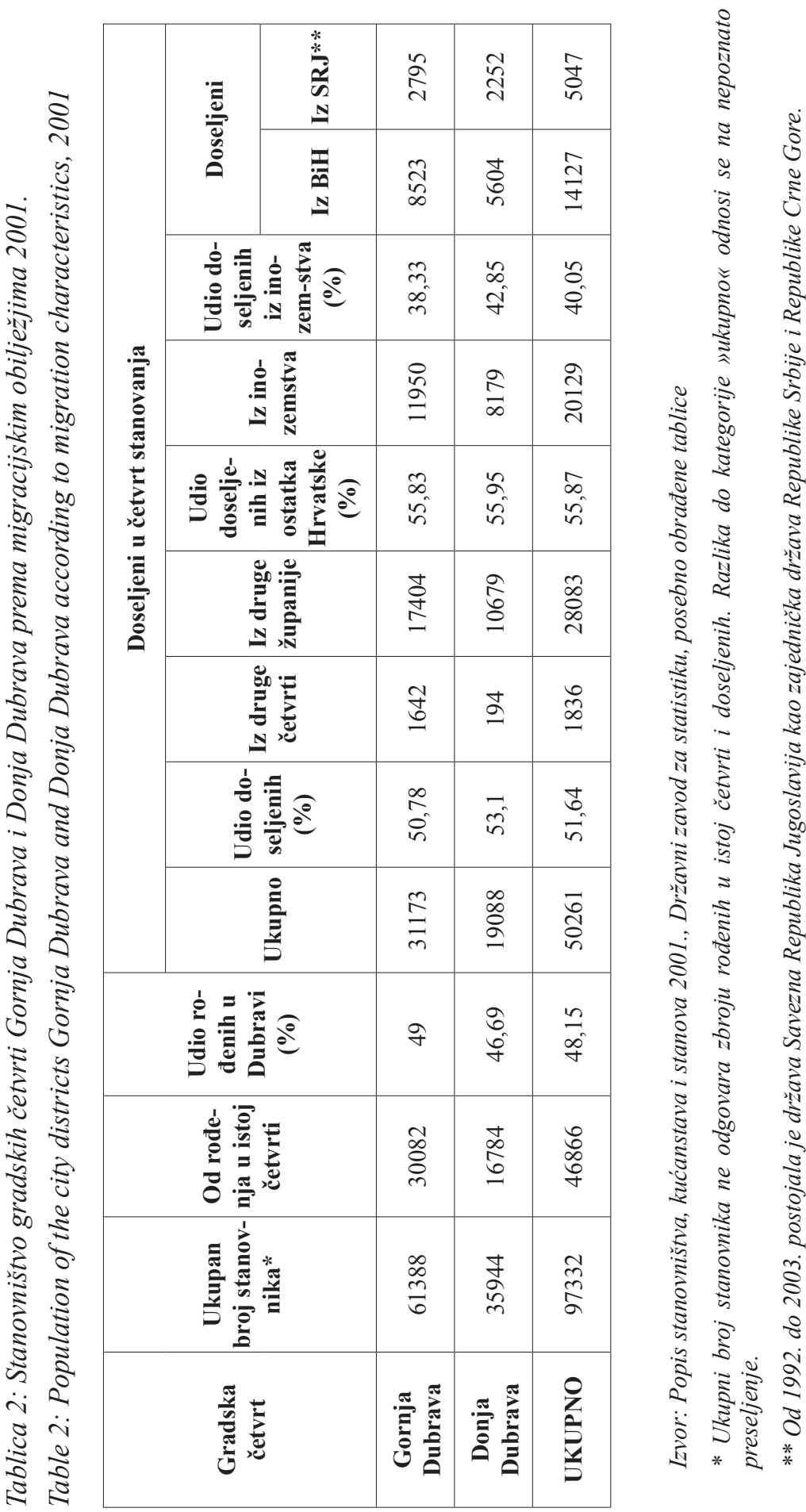
doseljenika došla iz bivše SRJ $(25,1 \%)$. U mnogo manjem udjelu, do ukupno 5\%, slijede doseljeni iz Makedonije, Slovenije, Albanije i dr. Dakle i službena statistika djelomično potvrđuje općeprihvaćeno, često negativno konotirano mišljenje da »u Dubravi živi veliki broj Bosanaca i Hercegovaca«. No na činjenicu da taj »veliki broj « i nije tako velik, odnosno da je, u najmanju ruku, diskutabilan i zasigurno posljedica vlastite percepcije, upućuje i udio doseljenika iz $\mathrm{BiH}$ u ukupnome stanovništvu Dubrave (14\%; u Gornjoj je Dubravi nešto niži, 13,9\%, a u Donjoj 15,6\%).

Slika 7 pokazuje u kakvu su prostornome i brojčanom odnosu udjeli dviju najvećih skupina doseljenika (iz drugih hrvatskih županija i $\mathrm{BiH}$ ) u ukupnome broju doseljenika. Očekivano, u većini statističkih krugova udio doseljenika iz drugih dijelova Hrvatske (osim Zagreba) nadmašuje udio imigranata iz BiH (najtamnije nijanse) od 1,1 do čak 5,2 puta. $^{13}$ Vidljivo je da se najveći udjeli doseljenika iz BiH nalaze na području Oporovca, Trnovčice, Granešinskih Novaka, južnoga dijela Jalševca, Granešine i Staroga Retkovca. To su ujedno dijelovi koji su, uz cijelu »užu« Dubravu, i drugima najatraktivniji za naseljavanje. Najnovija migracija stanovništva iz BiH koncentrira se i u područjima južno od željezničke pruge (Stari Retkovec, Resnik i Trnava).

Doseljenici iz bivše SRJ čine 10,4\% svih doseljenih, a u ukupnom broju stanovnika Dubrave tek oko 5\%. Naseljavaju i drugima najatraktivnije dijelove Dubrave. Valja pretpostaviti da su se do početka devedesetih godina 20. stoljeća naseljavali u većem broju nego danas.

Prema podacima popisa iz 2001., mali se, gotovo neznatni broj stanovnika iz ostalih zagrebačkih četvrti odlučuje preseliti u Dubravu (3,65\%), od čega nešto više $(5,27 \%)$ u Gornju Dubravu (to su vjerojatno oni koji ondje imaju vikendicu ili staru kuću, pa se presele u nju). Izgradnjom velikih stambenih zgrada u novim naseljima taj se broj povećava, kao što je bio slučaj s naseljavanjem stambenih zgrada u Novome Retkovcu i Poljanicama, kamo su se doseljavale uglavnom mlade obitelji s djecom iz ostalih dijelova Zagreba. Ipak, ti skromni podaci samo još jednom potvrđuju ukorijenjeni stav Zagrepčana da je Dubrava nepoželjna za život i sinonim za neugodu (Stiperski, 1997: 314).

13 Broj 1,0 upućuje na to da je udio obiju skupina u ukupno doseljenima jednak (vodoravna šrafura), dok nakošena (posljednja) šrafura označuje dijelove u kojima je udio doseljenika iz BiH veći od udjela doseljenih iz drugih županija. 
Slika 7: Odnos doseljenika iz drugih županija i iz BiH 2001. po statističkim krugovima

Figure 7: The ratio of immigrants from other counties and from Bosnia and Herzegovina by statistical circles

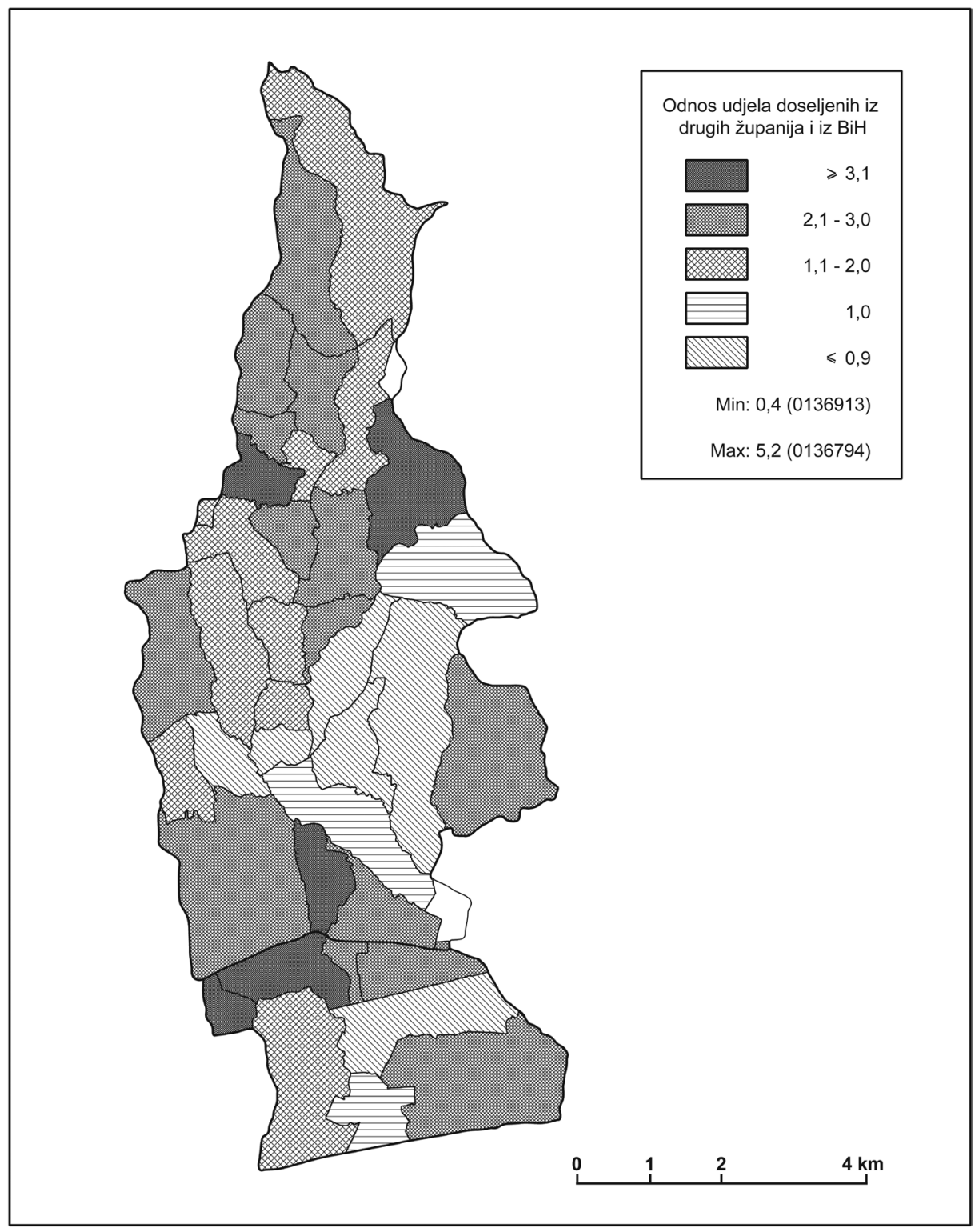

Izvor: Popis stanovništva, kućanstava i stanova 2001., Državni zavod za statistiku, posebno obrađene tablice 
Prema području prvobitnoga prebivališta, odnosno regionalnome podrijetlu, doseljeni etnički Hrvati u Dubravi nisu jedinstveni, što proizlazi iz činjenice da su se onamo doseljavali Hrvati iz gotovo svih dijelova Hrvatske, iz susjedne $\mathrm{BiH}$, iz Vojvodine i s Kosova. Odrediti granice u kojima žive Hrvati iz tih područja vrlo je teško jer, premda su u Dubravi zabilježeni primjeri etničke i rezidencijalne diferencijacije i segregacije (Brčić i Čaldarović, 1998: 68), izmiješanost stanovnika podrijetlom iz različitih područja u kojima žive Hrvati u Hrvatskoj i izvan njezinih granica u nekim je dijelovima Dubrave, osobito u Donjoj Dubravi, iznimno velika. Katkad je i stanovnicima koji ondje već godinama borave teško odrediti zone u neposrednom susjedstvu koje nastanjuju doseljenici iz pojedinih dijelova $\mathrm{BiH}$, ili neki drugi doseljenici, jer je riječ o ulicama ili čak dijelovima ulica kao razini podjele.

Premda nema točnih statističkih podataka o njihovoj rasprostranjenosti, među dubravačkom se populacijom ipak iskustveno zna koja područja u većoj mjeri nastanjuju Hrvati iz Bosanske Posavine, koja oni iz središnje BiH, koja većinom Hercegovci, a koja Janjevci. Tako će primjerice većina stanovnika Dubrave Trnovčicu poistovjetiti s Hercegovcima, Dubec i Retkovec s Posavcima, Konjščinsku i okolne ulice s Janjevcima, kao što će i za pojedine dijelove Donje Dubrave, premda je izmiješanost stanovništva ondje vjerojatno najveća, uglavnom znati reći odakle se i kada doselilo tamošnje stanovništvo.

O prvobitnome grupiranju doseljenika temeljenom na početnome prebivalištu, ali i o kasnijoj sve većoj izmiješanosti doseljenika iz različitih krajeva govore podaci nekih župa i sociološka istraživanja. Župa sa sjedištem u Trnovčici ima oko pet tisuća župljana, koji potječu uglavnom iz Hercegovine, Prigorja, Hrvatskoga zagorja, Dalmacije i Slavonije. Nakon rata došli su i mnogi iz Bosne i s Kosova (uglavnom iz Janjeva) (prema Družba Svećenika Srca Isusova...). Brčić i Čaldarović ističu »...segregiranje Janjevaca u samo neke dijelove Dubrave, primjerice, u Konjščinskoj ulici i u neposrednom susjedstvu; naseljavanje Hercegovaca u sjeverni dio područja (...) Posavaca i izbjeglih stanovnika iz Bosne i Hercegovine u Retkovec...« (1998: 68). Uzimajući u obzir da su se osim navedenih u Dubravu doselili i Srbi, Bošnjaci, Romi, Albanci, Slovenci i pripadnici drugih naroda (koji su s vremenom stekli status manjine), može se zaključiti da je u Dubravi prisutno stanovništvo različite etničke pripadnosti.

Da se takva etnička raznolikost odrazila na kulturne pejzaže »uže« Dubrave, odnosno one dijelove koji su nastali individualnom gradnjom (jer se u područjima planske visoke stambene gradnje razlike ne mogu vidjeti), nedvojbeno je većini Dubravčana. Kada ih se upita postoje li i gdje fizionomski odrazi različitih etničkih grupa stanovništva u kulturnim pejzažima Dubrave, uglavnom promptno odgovaraju da se etnički sastav može prepoznati u izgledu kuća, okućnica i sl. Primjer 
kojim se ta tvrdnja potvrđuje gotovo se uvijek i jedino svodi na razlike između Konjščinske ulice (koja je postala sinonimom za Janjevce) i drugih dijelova Dubrave, vjerojatno zato što su one u kulturnim pejzažima najuočljivije.

No izlaskom na teren utvrđeno je da su izrazito uočljive razlike, koje su vjerojatno u većoj mjeri postojale prije nekoliko desetaka godina, danas ipak mnogo manje vidljive u kulturnim pejzažima. Čini se da su dugogodišnji suživot stanovnika iz različitih područja doseljavanja i činjenica da ondje žive već drugi i treći naraštaj stanovnika rođenih u Dubravi, koji su rođeni u gradskoj sredini, pa imaju gradske životne navike svojstvene ostalim Zagrepčanima, kao i sveprisutni procesi kopiranja stilova gradnje i prenošenja trenutačne »mode« gradnje kuća (od odabira građevnih materijala, boja fasada i oblika kuća) i uređenja okućnica pridonijeli njihovu ujednačivanju. Tako je običnome šetaču vrlo teško prepoznati živi li u nekoj kući netko tko je podrijetlom iz primjerice Like ili Bosanske Posavine. Veće razlike u fizionomiji kuća, okućnica i ulica i drugim elementima kulturnoga pejzaža ponajviše su odraz razvoja morfološke strukture Dubrave (morfogeneze), a samo u nekim slučajevima i etničke strukture (npr. u područjima gdje žive Janjevci).

\section{PRIMJER UTJECAJA ETNIČKE STRUKTURE NA KULTURNE PEJZAŽE: KONJŠČINSKA ULICA}

Najbolji i najpoznatiji primjer trgovačke ulice u Dubravi, uz Ulicu Dubrava, zasigurno je Konjščinska. Dojam koji ta ulica s osebujnim kućama i mnoštvom prodajnih prostora ostavlja na većinu šetača i/ili kupaca može se izreći pojmom »drukčija«. S kućama koje svojim dimenzijama i stilom gradnje znatno odudaraju od okolice, ta je ulica različita po svojoj fizionomiji, po prevladavajućoj trgovinskoj funkciji i po svojim stanovnicima, što se izravno odražava na vizualni kulturni pejzaž tog dijela Dubrave.

Prije pedesetak godina Konjščinska ulica bila je posve obična dubravačka ulica u izgradnji, čije su prve kuće okruživala polja i drveće, a uz prve malobrojne janjevačke doseljenike ondje su uglavnom živjeli doseljenici iz Zagreba. Tijekom vremena, a ponajviše osamdesetih i devedesetih godina 20. stoljeća, doseljavanjem znatnijega broja Janjevaca s Kosova, Konjščinska je ulica postala sinonimom: a) trgovine i »jeftinog šopinga«, b) Janjevaca, c) golemih kuća kontroverzne estetike i d) kratkotrajnog poslovnog uspona i pada.

Dok su stručna i znanstvena literatura o Janjevcima u Dubravi ${ }^{14}$ u tolikoj mjeri deficitarne da je nužno oslanjanje na usmene izvore, o trgovini u Konjščinskoj,

14 Literatura o Janjevcima uglavnom se bavi poviješću Janjevaca na Kosovu, dokazivanjem njihova hrvatstva i njegove opstojnosti u teškim vremenima života na Kosovu te sociološkim poteškoćama prilikom asimilacije i adaptacije Janjevaca na novu životnu sredinu i njihovim uzrocima (Glasnović-Gajić, 1999-2000). 
njezinu poslovnom uspjehu te o estetski i arhitektonski dvojbenim suvremenim rješenjima izgradnje kuća u toj ulici napisano je više stručnih i novinskih tekstova. Tako opisujući izgled kuća, koje bi se s pravom mogle nazvati pravim arhitektonskim ekshibicijama, u jednome novinskom članku Raguž (2007) slikovito kaže da »zaista zaslužuju crveni karton«. U šaljivu tekstu »Learning from Konjščinska« uvodnika jednog broja časopisa Čovjek i prostor navodi se niz opisa koji vjerno predočavaju realno stanje u prostoru; na primjer: »Ni umjetnik s najvećom maštom ne može domisliti što naš čovjek može izvesti, a vidljivo je na morfološkoj raznolikosti prisutnoj u Konjščinskoj (...) Tu je inaugurirana tema garaže kao izuzetnoga poslovnog prostora, zatim tema svaki kat posebni entitet (...) Čini se da je doista važna invencija Konjščinske ta famozna 120 postotna izgrađenost parcele (...) Dubina parcele i balkoni, koji se prelijevaju na cestu, bitni su elementi Konjščinske« (1998: 6-7).

Premda u devedesetima u poslovnome smislu iznimno uspješna, Konjščinska je danas primjer ulice koja je u razmjerno kratkom vremenu doživjela svoj vrhunac i pad. Opisujući nekadašnje stanje Konjščinske, Raguž (2007) naglašava: »Gotovo pola stoljeća trgovci iz Konjščinske ulice u zagrebačkoj Dubravi bili su simbol snalažljivosti i dobre zarade (...) Velebne kuće i impresivne ergele BMW-a, Mercedesa i Porschea svjedočile su koliko su dobri u tome čime se bave (...) Ulica, kako je oni sami pojednostavljeno nazivaju, bila je puna ljudi. Roba se valjala, uvaljivala, gurala.«

U tih pedesetak godina, od početka šezdesetih, kada su, prema riječima predsjednika Hrvatskoga društva »Janjevo« Pavla Palića, u Dubravu stigli prvi Janjevci, Konjščinska se ulica izgrađivala, širila i nadograđivala kapitalom ostvarenim ili samostalnom zanatskom proizvodnjom i prodajom odjevnih i ukrasnih predmeta od metala i plastike ili prodajom takvih predmeta i kožne galanterije uvezenih iz Turske, Italije i s Dalekoga istoka. Osobito su bili cijenjeni kao zlatari. Dok se nejanjevačko stanovništvo postupno iseljavalo, Janjevci su se doseljavali. Tijekom vremena bogatili su se, pa su počeli gradili potpuno drukčije, zbijene kuće. Budući da su te nove građevine mješavina poslovno-prodajnoga dijela u prizemlju i/ili prvom katu te stambenoga prostora na katovima, uglavnom su to dvokatnice ili trokatnice (često nasumično poredane jedne pokraj drugih, op. a.), s isturenim radionicama ili trgovinama u prizemlju (Šiljković i Glamuzina, 2004: 104) okrenutima prema ulici. Prema Palićevim riječima, na veličinu kuća u Konjščinskoj utječe i još uvijek prisutna tradicija velikih obitelji s mnogo djece. Raguž (2007) kaže da postoji i treći faktor: prestiž među Janjevcima.

Fasade su uglavnom svijetlih boja (žuta, ružičasta, plava) ili su obložene mramorom i staklom, a na njihovim se pročeljima često mogu vidjeti razni ukrasni 
kipići i blještava rasvjeta, zaobljene, pretjerano ukrašene i kičaste ograde, prozori s plastičnom stolarijom i velike reklame za prodaju tekstila, remenja i sl. Na ulici je mnoštvo vješalica i lutaka s robom koje, prostirući se do ruba pločnika, uz parkirane automobile ometaju prolaz pješakâ. Malašić (2008) konstatira da »svaka veletrgovina u ulici nosi obiteljsko prezime, pa ulica neodoljivo podsjeća na veliko rodoslovno stablo«. Ulica je asfaltirana, ali nije ravna, već prati trasu prvobitne, spontano izgrađene ulice.

Tako je barem Konjščinska ulica izgledala do početka 21. stoljeća, kada su se u blizini »Ulice« i drugdje u gradu počele otvarati trgovine jeftine kineske robe, koje su ubrzo postale glavna konkurencija onima iz Konjščinske (Malašić, 2008; Raguž, 2007). Osim Kineza na smanjenje trgovačke djelatnosti utječu i veliki trgovački centri. Iste razloge u intervjuu navodi i P. Palić.

Zanimljivo je vidjeti što sami Janjevci misle o Konjščinskoj ulici i o percepciji koju o njima ima nejanjavačko stanovništvo, a koja je uvelike stvorena upravo zbog te ulice. Prema nekim novinskim anketama, dio Zagrepčana smatra da je riječ o imućnijim ljudima, sklonima škakljivim poslovima na rubu zakona, a mlade Janjevce svrstava se u klanove i dobro organizirane grupe za pritiske (Stažić, 1990: 4). Ipak, prema Stažiću, Janjevci ne vole kada se uopćava stajalište o njima, koje je posljedica slabe informiranosti. I P. Palić slaže se s tim tvrdnjama: »Ljudi obično smatraju da smo svi mi nekakvi bogataši i tajkuni. Možda bismo mi i voljeli da je tako, ali to, jednostavno, nije istina (...) Brojne obitelji s petero, šestero djece žive u podstanarskim sobama, nemaju nikakve, a ne skupe aute« (prema Raguž, 2007).

Iz svega navedenoga može se zaključiti da osnovni elementi morfološke strukture, kao što su izgrađenost ulice, vanjska obilježja kuća i okućnica, u Konjščinskoj ulici i dijelu okolnih ulica Križnoga puta te Banovičke i Derventske ulice, danas, kada je u njima radni kapacitet smanjen, izgledaju slično kao i u doba procvata prije dvadesetak godina. Iako su trgovine slabije popunjene robom i kupaca je manje, izvana i dalje sve uglavnom izgleda isto.

No nisu to jedini dijelovi Dubrave u kojima žive Janjevci. Drugi takvi dijelovi fizionomski se razlikuju od Konjščinske ulice. Prema Palićevim riječima, premda razasuti po cijeloj Dubravi, Janjevci u znatnijem broju žive i u području oko Južne ulice, Celovečke ulice sjeverno od Oporovečke ulice, ima ih i u Oporovcu, u području Janekovićeve parcelacije i u Donjoj Dubravi, osobito uz Branimirovu ulicu. Za razliku od Janjevaca u Konjščinskoj, ti su se Janjevci doseljavali nešto kasnije. U drugom valu tijekom osamdesetih godina 20. stoljeća (Švob, Brčić i Podgorelec, 1998: 20) počeli su se doseljavati u Donju Dubravu, a osobito u Južnu ulicu i oko nje, "zapravo svugdje gdje je bilo jeftino zemljište i gdje su već živjeli Janjevci« (Palić, intervju), u Gornju Dubravu do Tržne ulice i u Oporovec. Najnovija migra- 
cija, ona nakon rata na Kosovu 1992., koja traje do početka 21. stoljeća, najviše naseljava dotad neizgrađene dijelove Dubrave te se širi u navedenim područjima. Okupljanje janjevačkih obitelji u Dubravi, primjerice oko jedne ulice, rezultat je osjećaja povezanosti, sigurnosti i zajedničkoga života u novoj sredini. Stoga su gotovo svi pridošlice s Kosova gradili kuće i naseljavali se blizu svoje rodbine, prijateljâ i bivših susjeda (Šiljković i Glamuzina, 2004: 100; Crljenko, 2012b: 37).

Prema Paliću, nije problem samo omeđiti područje koje naseljavaju Janjevci, jer ih u manjoj ili većoj mjeri ima gotovo posvuda u Dubravi, nego je diskutabilan i njihov točni broj. Ipak, u literaturi se najčešće spominju podaci koje navodi i P. Palić: »...početkom 1990-ih (dakle prije velikog vala naseljavanja nakon 1992.) u Dubravi živjelo oko 4000 Janjevaca. U posljednjem je valu migracija iz Janjeva došlo još oko 3000 Janjevaca« (i prema Glasnović, 1995-1996: 24; Šiljković i Glamuzina, 2004: 100). Dakle s oko sedam tisuća pripadnika Janjevci čine tek oko sedam posto stanovnika Dubrave (Crljenko, 2012b: 36-37).

Drugim migracijskim valom, a osobito onim posljednjim s početka devedesetih, u Dubravu su se doselili Janjevci znatno drukčijega, nižega socijalnog statusa od onih koji su se doselili šezdesetih i sedamdesetih pa su se s vremenom obogatili i u većoj mjeri asimilirali s ostalim stanovnicima Dubrave. Razlike u socijalnom statusu tih dviju skupina Janjevaca očituju se i u kulturnome pejzažu koji oblikuju. Kasniji doseljenici u početku su gradili malene kuće, često bespravno i bez osnovne infrastrukture u područjima već prije nazvanima »Biafra« i »Palestina« (Šiljković i Glamuzina, 2004: 105). »Određeno su vrijeme živjeli kod svojih rođaka ili prijatelja, dok nisu podigli kakvu skromnu kućicu« (Glasnović, 1995-1996: 24).

No unatoč proteku vremena kuće se i dvadesetak godina poslije uglavnom bespravno šire, stvarajući nove ulice, koje nerijetko završavaju u poljima. Mnogi Janjevci pridošlice počeli su nadograđivati prvobitne kuće ili graditi nove, od kojih su neke goleme trokatnice slične onima u Konjščinskoj ulici. Takve promjene u fizionomiji svakako su odraz znatno boljega standarda od onoga doseljenikâ početkom devedesetih. Unatoč tome mnoge ulice ostaju neasfaltirane, neosvijetljene i neuređene, a mnogim kućama nedostaje fasada premda se u njima već dugo živi. Uočljiva su i sva ostala obilježja neuređene gradnje.

Iz priče o Janjevcima u Dubravi jasno je da pojedine etničke grupe, osobito ako se svojim obilježjima znatno razlikuju od okolnoga stanovništva te ako imaju tendenciju okupljanja u određenim dijelovima gradskoga prostora, bitno utječu na fizionomiju kulturnih pejzaža u kojima žive, jer pejzaž, kako je pokazao primjer izgradnje golemih prodajno-stambenih kuća u Konjščinskoj ulici, vlastitim načinom života prilagođavaju sebi. 


\section{ZAKLJUČAK}

Analizom nekih demografskih obilježja Dubrave, ponajviše migracijskih i etničkih, i njihovih odraza u suvremenome kulturnom pejzažu može se zaključiti da je porast broja stanovnika Dubrave nakon Drugoga svjetskog rata u velikoj mjeri povezan sa širenjem njezine morfološke strukture, odnosno da su ta dva procesa u uzročno-posljedičnoj vezi te su dvosmjerna. S povećavanjem broja stanova povećavao se i broj stanovnika, što pokazuje useljavanje u planski izgrađene stambene zgrade, i obratno, kako se povećavao broj doseljenika, rastao je i broj obiteljskih kuća, što dokazuje činjenica da je poticaj za širenje stambenog fonda najčešće dolazio od doseljenika, a ne od planerskih institucija i Grada. Rezultat toga veliki je udio neplanske, stihijske gradnje, osobito u Donjoj Dubravi. U analizi se izdvojio zanimljiv podatak prema kojemu Dubrava već gotovo tridesetak godina nije tipično područje doseljeničkog tipa; polovinu stanovništva danas u njoj čine stanovnici rođeni u Dubravi. Rezultat je to njezine dugovječnosti - od prvih parcelacija zemljišta i početaka izgradnje »uže« Dubrave tridesetih godina 20. stoljeća prošlo je osamdesetak godina. Isto tako, problematizirana je raširena percepcija da u Dubravi živi mnogo doseljenika iz $\mathrm{BiH}$, jer se pokazalo da oni čine tek sedminu ukupnoga stanovništva Dubrave.

Terensko je istraživanje pokazalo da se vidljivi odrazi koje u pejzažu ostavljaju različite skupine doseljenika s vremenom smanjuju i/ili gotovo nestaju. Naime prvi doseljenici ostavljali su daleko vidljiviji trag u pejzažu individualnom gradnjom nego što se to čini danas, pa se moglo prepoznati u kojemu području žive koji doseljenici. Ipak, iskustveno se još uvijek zna gdje žive primjerice Posavci, Hercegovci, Ličani ili Janjevci. Nestajanje tragova u pejzažu posljedica je velike izmiješanosti svih stanovnika Dubrave, bez obzira na raznolikost podrijetla. Osim toga sveprisutni procesi kopiranja stilova gradnje i trenutačne mode gradnje kuća i uređenja okućnica pridonijeli su njihovu ujednačivanju.

Jedini evidentan primjer utjecaja jedne etničke grupe na kulturni pejzaž Dubrave jest Konjščinska ulica. Ona je doseljavanjem znatnijega broja Janjevaca s Kosova osamdesetih i devedesetih godina 20. stoljeća postala, prije svega, sinonimom za trgovinu i goleme kuće. Ulicom dominiraju velike dvokatnice ili trokatnice kontroverzne estetike, $\mathrm{s}$ isturenim trgovinama u prizemlju. Bez obzira na opadanje poslovne funkcije zbog koje su i građene u takvim dimenzijama, jasno upućuju na prevladavajuće djelatnosti etničke grupe koja u njima živi. U radu se ističe da kulturna i tradicijska posebnost Janjevaca (njihov način života i vrijednosti koje zagovaraju), više nego etnička (ovdje ih se razmatra kao etničku grupu), utječe na stvaranje i promjenu pejzaža u kojemu žive. Budući da dubravački Janjevci ne žive samo u Konjščinskoj ulici i oko nje, nego su raspršeni gotovo svuda po Dubravi 
(što otežava bilo kakve precizne zaključke), bilo bi zanimljivo u nekom sljedećem istraživanju usporediti fizionomske odraze koje u pejzažu ostavljaju Janjevci doseljeni u različitim fazama naseljavanja (od onih prvih u Konjščinskoj ulici do onih doseljenih tijekom i nakon Domovinskoga rata u više područja). Za to je međutim potrebno provesti opsežno interdisciplinarno geografsko-urbanističko-sociološko istraživanje trenutačnoga (i prošloga) stanja »janjevačkih« pejzaža.

\section{LITERATURA}

BRČIĆ, Carmen, ČALDAROVIĆ, Ognjen (1998). »Položaj mladih u Dubravi (Zagreb): socijalna integracija i dezintegracija«, Migracijske teme, Zagreb, 14 (1-2): 65-77.

CRKVENČIĆ, Ivan (1968). „Socijalno-geografska struktura stanovništva rubnih dijelova Zagreba«, u: Zbornik na VIII kongres na geografite od SFRJ. Skopje: Geografsko društvo na SR Makedonija, str. 253-266.

CRLJENKO, Ivana (2008). »Izraženost identiteta u gradskoj toponimiji kvarnerskih i istarskih gradova«, Hrvatski geografski glasnik, Zagreb, 70 (1): 67-90.

CRLJENKO, Ivana (2012a). »Utjecaj nekih sociogeografskih čimbenika na morfogenezu zagrebačke Dubrave«, Hrvatski geografski glasnik, Zagreb, 74 (1): 111-139.

CRLJENKO, Ivana (2012b). »Dubrava u zagrebačkom okruženju«, Geografski horizont, Zagreb, 58 (1): $27-42$.

Družba Svećenika Srca Isusova (dehonijanci) u Hrvatskoj, župa Marija Majka Crkve, Trnovčica, http://scj.hr/index.php?tekst=84 (12.04. 2010).

GLASNOVIĆ, Matej (1995.-1996). »Kalvarija koja traje«, Zvono: janjevački godišnjak, Zagreb, (2): $23-25$.

GLASNOVIĆ-GAJIĆ, Ljiljana (1999-2000). »Kako prevladati tradicionalizam«, Zvono: janjevački godišnjak, Zagreb, (6): 47-49.

GLOBAREVIĆ, Ilija (1974). Socijalno-geografska problematika rubnih zona Zagreba na primjeru Dubrave (magistarski rad). Zagreb: Prirodoslovno-matematički fakultet Sveučilišta u Zagrebu.

KATUNARIĆ, Vjeran, PODGORELEC, Sonja i ŠVOB, Melita (1998). „Crkva i disko: sociokulturni kontekst i orijentacije mladih u zagrebačkoj Dubravi«, Migracijske teme, Zagreb, 14 (1-2): 33-64.

KVOČIĆ, Krešimir (1984). »Što o nama kazuju brojke?«, Dubrava - list radnih ljudi i građana općine Dubrava-Zagreb, Zagreb, (74): 5.

LADOVIĆ, Vanda (1960). »Pregled razvoja zagrebačke Dubrave«, u: Franjo Buntak i dr. (ur.). Iz starog i novog Zagreba, II. Zagreb: Muzej grada Zagreba, str. 299-309.

Leksikon migracijskoga i etničkog nazivlja (1998). Zagreb: Institut za migracije i narodnosti Školska knjiga.

»Learning from Konjščinska« (uvodnik) (1998), Čovjek i prostor, Zagreb, 45 (9/12): 6-7.

LEWIS, Peirce F. (1979). »Axioms for Reading the Landscape: Some Guides to the American Scene«, u: Donald W. Meinig (ur.). The Interpretation of Ordinary Landscape: Geographical Essays. New York - Oxford: Oxford University Press, str. 11-32. 
MALAŠIĆ, Gordana (2008). »Foto: zbog Kineza Konjščinska polako umire«, Dalje.com, obj. 23. 6. 2008., http://dalje.com/hr-zagreb/foto--zbog-kineza-konjscinska-polako-umire/1576911 (05. 04. 2010).

NEJAŠMIĆ, Ivo (1994). »Populacijski razvitak Zagreba«, Sociologija sela, Zagreb, 32 (1/2): $1-12$.

RAGUŽ, Krešimir (2007). »Pad Konjščinske«, Jutarnji list, obj. 7. 4. 2007., http://www.jutarnji. hr/pad-konjscinske/169538/ (12. 05. 2009).

STRUKIĆ, Kristian i ANTOŠ, Zvjezdana (2012). »Mali poduzetnici«, u: Kristian Strukić (ur.). Katalog izložbe Zagrebačka Dubrava od predgrađa do grada. Zagreb: Muzej grada Zagreba, str. 67-73.

STAŽIĆ, Igor (1990). »Dubrovčani u Dubravi«, Dubrava - list radnih ljudi i građana općine Dubrava-Zagreb, Zagreb, (169): 4.

STIPERSKI, Zoran (1997). »Mjesta u Zagrebu - sinonimi za ugodu i neugodu«, Prostor, Zagreb, $5(2): 307-320$.

ŠILJKOVIĆ, Željka i GLAMUZINA, Martin (2004). »Janjevo and Janjevci - from Kosovo to Zagreb «, Geoadria, Zadar, 9 (1): 89-109.

ŠVOB, Melita, BRČIĆ, Carmen i PODGORELEC, Sonja (1998). »Mladi u Dubravi«, Migracijske teme, Zagreb, 14 (1-2): 7-32.

WINCHESTER, Hilary P. M., KONG, Lily i DUNN, Kevin (2003). Landscapes: Ways of Imagining the World. Harlow, Essex: Pearson Education.

\section{IZVORI}

KORENČIĆ, M. (1979). Naselja i stanovništvo SR Hrvatske 1857-1971. Zagreb: Jugoslavenska akademija znanosti i umjetnosti.

Popis stanovništva 1857-2001, Naselja i stanovništvo Republike Hrvatske 1857-2001. CDROM, DZS, Zagreb, 2005.

Popis stanovništva 1948, Konačni rezultati popisa stanovništva od 15. marta 1948. godine: Stanovništvo po polu i domaćinstva, knjiga I. Savezni zavod za statistiku i evidenciju, Beograd, 1951.

Popis stanovništva 1961, Popis stanovništva 1961: stanovništvo i domaćinstva u 1948., 1953. i 1961., knjiga X. Savezni zavod za statistiku, Beograd, 1965.

Popis stanovništva 1981, Stanovništvo, domaćinstva i stanovi po mjesnim zajednicama (stanje popisa 31. 3. 1981.). Centar za ekonomski razvoj grada Zagreba - Zavod za statistiku, Zagreb, 1982.

Popis stanovništva 2001, Popis stanovništva, kućanstava i stanova 2001, Državni zavod za statistiku, http://www.dzs.hr/ (17. 10. 2009).

Popis stanovništva 2011, Državni zavod za statistiku, http://www.dzs.hr/Hrv/censuses/ census2011/results/censustabshtm.htm (17. 12. 2012).

Posebno obrađene tablice popisa 2001. za gradske četvrti Gornja i Donja Dubrava po statističkim krugovima, Državni zavod za statistiku, Zagreb, 2010.

Statut grada Zagreba, Službeni glasnik Grada Zagreba, http://www1.zagreb.hr/slglasnik.nsf (10. 09. 2012). 
Ivana CRLJENKO

\title{
Migration and Ethnic Characteristics of the Population as Factors of the Cultural Landscape Transformation in the Dubrava District in Zagreb
}

\begin{abstract}
SUMMARY
Migration and ethnic characteristics of the population, along with the general population trend, population density as well as the age, socioeconomic, racial and even gender structure of the population, have an impact on the transformation of cultural landscape of an area. It has been shown here on the example of the Dubrava district in Zagreb by analyzing the basic demographic indicators and their reflections on the visible space. A case study has been applied to explore the impact of Janjevci on a part of the Dubrava landscape, more precisely on one shopping street - Konjščinska Street. The research has shown that Dubrava, i.e. its "narrow" centre, was largely populated during the period from 1950 to 1970 , and that the population growth was mostly influenced by immigration from other parts of Croatia, and from Bosnia-Herzegovina. Although the first immigrants left their mark on the landscape in which they had settled, so that it was possible earlier to identify the area in the parts with individual house building where different groups of immigrants lived, today this is almost or even completely unnoticed. A long-time co-existence and recent trends of copying in both construction and garden decoration have reduced or completely erased the differences in the cultural landscape. The effects that one ethnic group can have influence on a directly visible cultural landscape can be noticed only in the enormous, aesthetically, functionally and physiognomically substantially different houses in Konjščinska Street.
\end{abstract}

KEY WORDS: cultural landscape, population, immigration, ethnic structure, Janjevci, Konjščinska Street, Dubrava 